\title{
THE EFFECTIVENESS OF SOIL AND WATER CONSERVATION TERRACE STRUCTURES FOR IMPROVEMENT OF CROPS AND SOIL PRODUCTIVITY IN RAINFED TERRACED SYSTEM
}

\author{
Muhammad Rashid ${ }^{1, *}$, Obaid ur Rehman', Sarosh Alvi², Rahina Kausar' ${ }^{1}$ and M. Imran Akram ${ }^{1}$ \\ ${ }^{1}$ Soil and Water Conservation Research Station, Fateh Jang, Pakistan; ${ }^{2}$ Soil Fertility Survey and Soil Testing \\ Institute, Rawalpindi, Pakistan \\ *Corresponding author's e-mail: rashid_hameedi@hotmail.com
}

\begin{abstract}
Depletion of soil moisture and soil nutrients by run-off is a serious problem in many parts of sloppy rainfed tract of Pakistan particularly in Fateh Jang areas. Terrace Structures (TS) are one of the important measures to enhance the water conservation and to check depletion of essential nutrient elements to obtain maximum crop yield on sloppy lands. A study was executed to assess the performance of TS regarding run off interception to conserve soil moisture and soil fertility for wheat production in uneven terrain of rainfed region. Wheat was sown on the upstream of TS consisting of two major blocks; Recommended Rate of Fertilizer (RRF) and Farmer Practice (FP) while under both there were two sub-blocks; With Terrace Structure (WTS) and Without Terrace Structure (WOTS) which hence constitute four treatments consisting of Recommended Rate of Fertilizer with Structure (RRFWS), Recommended Rate of Fertilizer Without Structure (RRFWOS), Farmer Practice With Structure (FPWS) and Farmer Practice Without Structure (FPWOS). Results of this experiment revealed that TS has increased the wheat grain yield significantly (20\%) through conservation of soil moisture contents $(16 \%)$ and soil fertility level. TS had decreased the gullies/rills formation through the efficient removal of excess rainwater.
\end{abstract}

Keywords: Water conservation terrace structures, water-harvesting structures, rainfed, wheat production

\section{INTRODUCTION}

Water is essential for all including human, animal and vegetation. It becomes even vital in rainfed region. Soil water has a variable impact under different soil environments. Soil water heterogeneity gives the best understanding in utilizing the terraced lands for suitable crops to reduce the soil erosion (Gardner and Gerard, 2003). Various scientists have studied the variability of soil water in different ecosystems and their effect on crop growth on the terraced and sloppy lands (Fu et al., 2000; Qiu et al., 2003). Soil erosion and water loss hazards in rainfed areas are very severe. Researchers indicated that erosion induces a significant depletion in soil fertility and crop production. The erosion hazards cause loss of soil fertility, deterioration of soil particles aggregation, decrease rooting depth and decreased soil storage capacity for crop production, which is based on the quality of the soil physical, chemical and biological properties (Ali et al., 2006). Destruction of fertile soils is a critical issue of concern during the last many decades due to its adverse impact on crop productivity (Eswaran et al., 2001; Lal, 2001).

Fateh Jang is situated in Pothowar Plateau of Pakistan. Unreliable rainfall and runoff are major limitations of this rainfed region. The synthesis of runoff is mainly due the torrential rains and poor soil fertility. The annual rainfall ranges from $700-1000 \mathrm{~mm}$. About $70 \%$ is recorded in the summer and the left behind 30\% in winter and the rainfall is enormously uneven and occasionally drought also occur (Yousaf, 2007). The soils of these areas are mainly derived from loess, piedmont and river alluvium material which are originated from the Sandstone and Shale. To solve the degradation problem, various measures like crop and soil management practices can be adopted to control soil losses and conserve the fertility of the soil to avoid the deterioration of soil physico-chemical properties. Conservation experts have proposed the embankment of fields with stone to intercept the runoff and manage water erosion (Mando et al., 2000).

TS are barrier constructed against the slope with loose stones that to slows down the runoff and sediment flow. These structures diminish the velocity of run-off which consequently captures the sediments there by improving the crop growth and yield. This method is very appropriate to the areas having an adequate and cheap availability of stones. TS can harvest enough runoff to increase soil moisture and enhance the fertilizer use efficiency. They also, guard the fields from adverse effects of high intensity rains. Establishment of concrete structures for this purpose is very expensive and is beyond the access of farmers of this region because of their poor financial condition. So, to develop a suitable cheap strategy to control water erosion, this experiment was executed to monitor the performance of TS on sloppy terraced lands. Numerous soil properties including soil organic matter, soil fertility, soil aggregation, and water 
retention and water transmission determine the soil condition and crop yield (Kaihura et al., 1999). The goal of this experiment was to assess the technical effectiveness of TS in the area, with regard to soil moisture conservation and wheat yield and their effect on soil properties.

Designing criteria of TS: To estimate the release run off (Q), rainfall intensity (I), Coefficient (C) and Area of catchment are needed (Fig 1). To plan a TS for a period of 30 years, the value of Intensity (I) was assumed 4 inches per hours. The runoff coefficient (C) was assumed 0.4 for the cultivated soils under the slope $0-5 \%$ and medium textured soil. So, on basis of the standard values of rainfall intensity (I) and coefficient of runoff $(\mathrm{C})$, peak discharge $(\mathrm{Q})$ could be estimated as:

$\mathrm{Q}=\mathrm{CIA}, \mathrm{Q}=1.6 \mathrm{~A}, \mathrm{~A}=$ Drainage area (acres), $\mathrm{Q}=$ Discharge $\left(\mathrm{ft}^{3} \mathrm{~s}^{-1}\right), \mathrm{I}=$ Rainfall intensity (inches $\mathrm{hr}^{-1}$ )

The TS may be planned by using broad crested Weir formula (FAO, 1990).

$$
\mathrm{Q}=\frac{3.1 \mathrm{~L} \mathrm{H}}{1.5}
$$

Where, $\mathrm{H}$ (feet) =Total depth of structure (including free board), F (feet) = Net drop, L (feet) = Length of the structure (FAO, 1990)

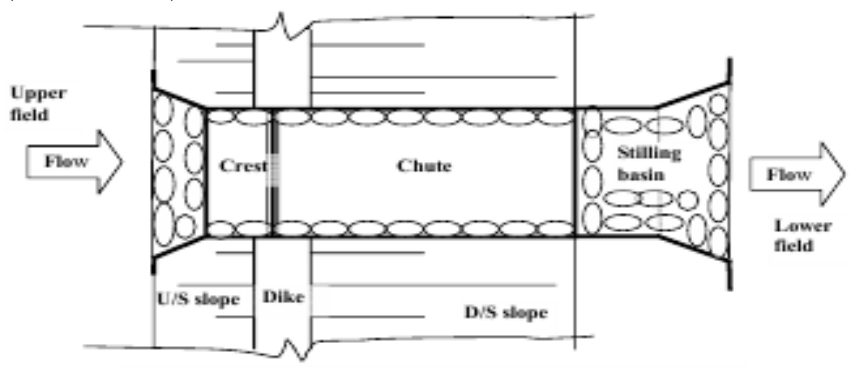

Figure 1. Schematic layout plan of TS.

\section{MATERIALS AND METHODS}

Location, climate and soils: TS were developed at Fateh Jang (Attock), latitude $33.55^{\circ} \mathrm{N}$, longitude $72.58^{\circ} \mathrm{E}$ and 402 $\mathrm{m}$ high from the sea level: situated on sloppy terraced lands prone to gully development. The location of this experiment have semi-arid climate having annual rainfall range 700-1000 $\mathrm{mm}$. During 2005 to 2010, annual rainfall varied from 398 $\mathrm{mm}$ to $902 \mathrm{~mm}$. Rainfall is summer dominant and only about $30 \%$ of the average annual rainfall occurs during the wheat growing season (October-April). The mean maximum temperature ranges up to $40^{\circ} \mathrm{C}$ in May-June, while the mean minimum temperature of 2.2 to $4.7^{\circ} \mathrm{C}$ occurs during December and January (Ahmad et al., 2006). The soils of the study areas are categorized as moderately deep, well drained, fine textured, calcareous loess deposited (Reconnaissance Soil Survey, Campbellpur, 1970).

Experimental details: This study was conducted during 200510 at the farmer's field, Kharala, Fateh Jang by Soil and Water Conservation Research Station (SAWCRS), Fateh Jang (Attock). Wheat was cultivated at upstream of TS to monitor the performance of TS in contrast with without TS field and its effects on wheat yield, soil moisture contents and on soil fertility status. In the experiment there were two major blocks; RRF and FP while under both there were two sub-blocks; WTS and WOTS which hence constitute four treatments consisting of RRWS, RRWOS, FPWS and FPWOS. All the treatments were arranged in Randomized Completely Block Design (RCBD) and were replicated thrice. In the RRFWS and RRFWOS, NPK was applied @ 120, 80, $60 \mathrm{~kg} \mathrm{ha}^{-1}$ year $^{-}$ ${ }^{1}$ in the form of Urea, DAP and SOP. Whereas, in FPWS and FPWOS farmers had applied the FYM @ 1 ton ha ${ }^{-1}$ after every two years and urea @ $50 \mathrm{~kg} \mathrm{ha}^{-1}$ every year and DAP @ 50 $\mathrm{kg} \mathrm{ha}^{-1}$ after every 3 years. Wheat variety Aquaab-2000 was sown every year.

Installation of TS: The estimated price of concrete structures is varied from Rs. 20,000 to Rs. 100,000 per structure. Such structures are established from bricks and cement. We have developed TS without bricks and cement, using only loose stones across each terrace slope just apart from peak discharge area allowing maximum conservation/retention of soil and water. One or two TS were developed per hectare considering the topography and soil features of field. After the establishment of TS within few months, natural grasses were raised in the gaps of loose stones which had provided cementing of stones. Therefore, the cost of the TS was far below than those of cement and brick structures. The average cost of TS was Rs. 3300 per TS for one hectare.

Soil sampling and analysis: A compound soil sample was obtained from the study site before the execution of the study to conduct physico-chemical analysis to assess the status of soil before this study (Table 1). After this, soil samples were obtained from $0-15 \mathrm{~cm}$ before sowing of wheat from each treatment for soil moisture determination and for physicochemical estimations before sowing of wheat to assess the change in soil due to TS. Soil samples were air-dried and passed through $2 \mathrm{~mm}$ sieve before chemical analysis. Soil $\mathrm{pH}$ and $\mathrm{EC}_{\mathrm{e}}$ were measured by the methods described by McLean (1982) and Richards (1954) respectively. Soil organic matter (Walkley, 1947), Extractable K (Rhoades, 1982) while soil available $\mathrm{P}$ was determined by (Watanabe and Olsen, 1965) and soil texture by Bouyoucus method (Gee and Bauder, 1986). Soil moisture contents were determined by gravimetric method (American Society of Agronomy, 1965). All laboratory determinations were carried out at SAWCRS, Fateh Jang.

Table 1. Physico-chemical characteristics of study area soil

\begin{tabular}{|c|c|}
\hline pH & 8 \\
\hline $\mathrm{EC}_{\mathrm{e}}\left(\mathrm{dS} \mathrm{m}^{-1}\right)$ & 0.96 \\
\hline O.M. (\%) & 0.62 \\
\hline $\mathrm{P}_{2} \mathrm{O}_{5}\left(\mathrm{mg} \mathrm{kg}^{-1}\right)$ & 2.84 \\
\hline $\mathrm{K}_{2} \mathrm{O}\left(\mathrm{mg} \mathrm{kg}^{-1}\right)$ & 56 \\
\hline Volumetric Saturation (\%) & 26 \\
\hline Textural Class & Sandy Loam \\
\hline
\end{tabular}


Crop data: At the end of each growing season, plots were manually harvested, one $\mathrm{m}^{2}$ sample of wheat was collected from every treatment and dry grain yield was determined.

Rainfall ( $\mathbf{m m})$ : Rainfall and mean monthly temperature (2005-10) was recorded at experimental site (Fig. 2 and 3).

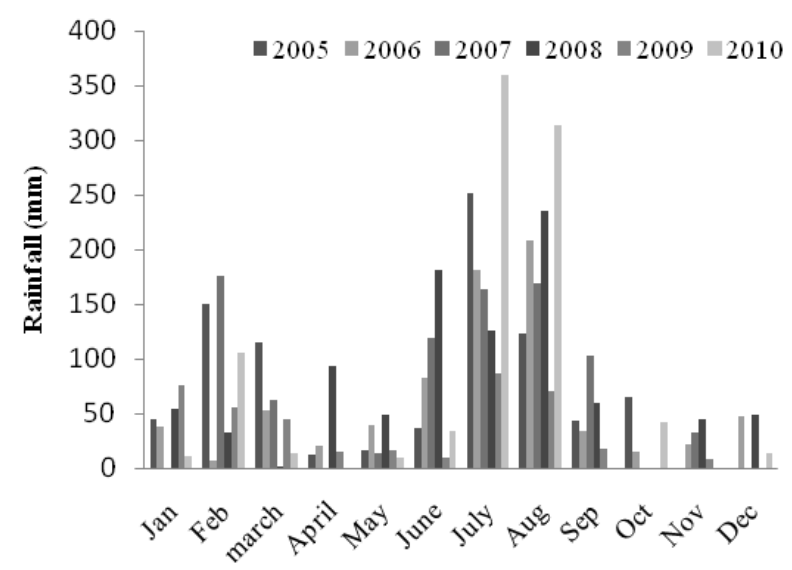

Figure 2. Rainfall Distribution at Study Site

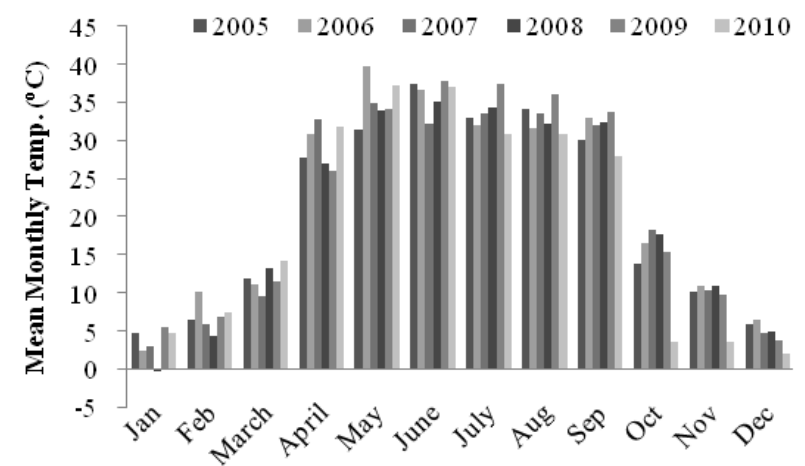

Figure 3. Mean monthly temperature at Study Site

Statistical analysis: Statistical analysis was made through the methods described by Steel et al. (1997) and M-Stat C computer model was applied to quantify the differences in wheat yield and soil characteristics.

\section{RESULTS AND DISCUSSION}

Performance of TS: TS were visited regularly after every rainfall event and the following data was recorded for evaluation of their performance:

i. Stability of stones: For the assessment of the stability of TS, after every rain storm the position and the stability of laid stones were observed and it was noticed that accumulation of soil particles and the natural grasses grown in the stones had strengthened the TS. When and where, if, any stone found displaced was fixed on spot without the involvement of labour force. It was observed during the study that with the passage of time no major damage/displacement of stones was observed and the surplus run off was passed securely. It was noticed that these TS helped in reducing run off velocity which consequently enhanced the infiltration of rain water. The structures harvested adequate runoff, so there was improved soil moisture and positive crop response to fertilizer. Akhtar et al. (2004) reported 20-25\% increase in crops yield at TS which confirms the findings of this experiment.

ii. Gully development: Torrential rains in these areas was creating gullies but these TS had greatly minimized the water erosion and gully development at upstream and downstream due to run off. TS had safely disposed the run off however; minor rills found at downstream were repaired. Nasri et al. (2004) observed that any soil and water conservation measure can retain all run off. Xiang et al. (2004) investigated in a study that stone check dams minimized the sediment loss and the gully development on sloppy lands. Tesfaye (2008) revealed that soil and water conservation measures including soil bunds are effective in minimizing soil erosion and have the ability to enhance soil productivity.

iii. Hydrological performance of TS: Height of water passed over the crest of the TS, was calculated to monitor its drainage and disposal performance. Saleh et al. (2009) reported a significant decrease in run off of rain water through check dams on sloppy areas. Drainage performance of TS was assessed by monitoring disposal of rain water through them (Table 2).

Table 2. Effect of highest rainfall event on TS.

\begin{tabular}{cccc}
\hline Year & $\begin{array}{c}\text { Total } \\
\text { rainfall } \\
(\mathbf{m m})\end{array}$ & $\begin{array}{c}\text { Highest rainfall } \\
\text { event }(\mathbf{m m})\end{array}$ & $\begin{array}{c}\text { Height of water } \\
\text { passed over crest } \\
(\mathbf{c m})\end{array}$ \\
\hline 2005 & 857 & 200 & $1.50-2.50$ \\
2006 & 745 & 151 & $0.75-1.50$ \\
2007 & 837 & 201 & $3.25-4.50$ \\
2008 & 925 & 335 & $3.00-6.50$ \\
2009 & 398 & 143 & $0.75-1.25$ \\
2010 & 902 & 462 & $4.00-7.25$ \\
\hline
\end{tabular}

Response of wheat grain production: TS can increase the fertility and productivity of soils in semi arid tract by increasing the water holding capacity of soils by the effective retention of rain water. Soil moisture conservation like TS is established to boost the maximum crop yields on sloppy/terraced lands. Wheat is the most important crop of Pakistan being the major staple food. Crop yields in rainfed region are often very low due to intensive erosion, infertile soils and erratic rainfall. During this experiment it was observed that practice of establishing TS has increased wheat grain yield significantly (Fig. 4). Maximum crop yield (3900 $\mathrm{kg} \mathrm{ha}^{-1}$ ) was recorded in 2006-07 in RRFWS while the lowest wheat yield (1553 $\left.\mathrm{kg} \mathrm{ha}^{-1}\right)$ was recorded in FPWOS in 200910. It was $13 \%$ higher than RRFWOS, $15 \%$ than FPWS and $19 \%$ more than FPWOS in same year. More or less, the same 
pattern in wheat yield was followed in all study years. Five years (2005-10) average accumulated yield data depicted maximum $20 \%$ increase in wheat yield. Furthermore, it was observed that response was best and evident in RRFWS which may be attributed to better fertilizer use efficiency in presence of enhanced soil moisture conserved by TS and better availability of soil nutrients by reduction in run off losses. The increase in crop yield was not directly related to rainfall. In some cases like 2008-09 where higher rainfall might have favoured the weeds infestation which may have reduced the crop yield to some extent. It was also noticed that poor financial condition of the farmers in the study area is not allowing incorporating the appropriate inputs to achieve maximum crop yield reason why the wheat yield during this study was lower in FP compared to RRF treatments.

Torrential rains in Monsoon cause heavy run-off creating gullies in this particular region lead to depletion of top fertile soil layer, therefore TS may have reduced the chance of erosion and nutrients loss but TS may have provided enough time for conservation of soil moisture and essential nutrients by reducing the run-off and over land flow (Prinz et al., 1996; Bosshart, 1997). The benefits of TS can be obtained soon after their construction but response in terms of higher grain yield may take some time. Results of this study are in line with Vancampenhout et al. (2003) who reported up to 53\% increase in crop yield by establishing stone bunds. Drought can reduce grain yield up to $50 \%$ compared with well irrigated wheat (Garcia et al., 2003) and soil and water conservation structures improve the crop yield by mitigating the drought problem (Ayalew, 2011). Zougmore et al. (2002) assessed in a similar study that stone lines have a restricted result on improving soil fertility and increasing crop yield after five years confirming the findings of Shemdoe et al. (2009) who revealed that assessing the soil fertility by crop yield alone is not reasonable because crop performance is a function of many factors including soil nutrient, presence of soil moisture contents, and weed epidemics as on degraded lands yield can be enhanced by fair use of fertilizers (Izaurralde et al., 2006). Furthermore, it is also an established fact that presence of adequate soil moisture enhances fertilizer application efficiency (Mando, 1998).

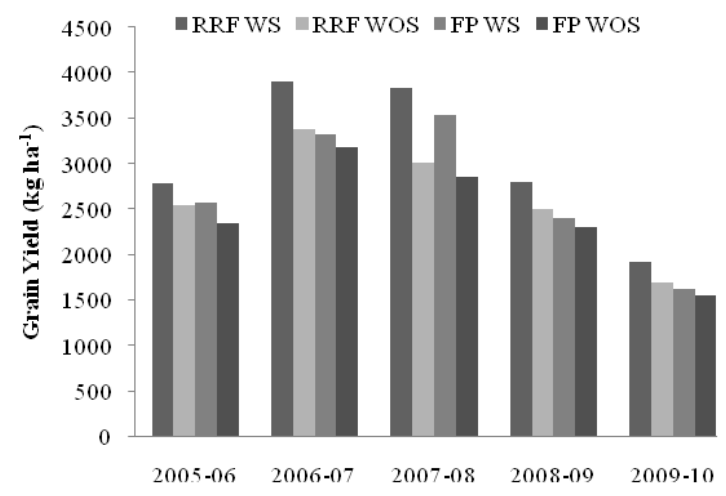

Figure 4. Effect of TS on wheat grain yield
Change in soil fertility status: Soil fertility status of rainfed eroded soils is generally deficient particularly that of phosphorus, may be due to water erosion and inadequate addition of fertilizers and other organic nutrient sources never the less the lands are under continuous cropping since long. This could be one of reason for soil and water erosion and nutrient depletion which consequently lead to land degradation. Farmers normally apply the local materials and other practices like manure application and agronomic practices to combat soil degradation and to enhance soil productivity because the raising fertilizer prices and access to suitable soil and water conservation technologies is a main reason to use their own logics. Significant differences were noticed in the chemical characteristics through adoption of TS (Fig. 5, 6 and 7). Runoff sweeps away fertile soil and promotes the soil erosion which ultimately causes the degradation of lands (Schiettecatte et al., 2005). Rashid and Qayyum (1990) reported about the study area that fields of these areas are deficient $70 \%$ in N, 67\% in P, 20\% in K, 64\% in $\mathrm{B}$ and $70 \%$ in $\mathrm{Zn}$. In Pakistani soils deficiencies $\mathrm{P}, \mathrm{Zn}$ and $\mathrm{B}$ are due to high $\mathrm{pH}$, calcareousness and low organic matter content the erosion further promote this hazard (Ahmad and Rashid, 2003). TS has changed the status of soil organic matter significantly never the less soil and water conservation measures need long time to mark any serious impact as erosion do not allow to develop soil structure. Data showed that organic matter content was increased from 0.66 to $1.11 \%$ in RRFWS while it was decreased from $0.68 \%$ to $0.60 \%$ in FPWOS (Fig. 5). Physical soil conservation measures activities can conserve the soil and improve soil fertility (Safene et al., 2006) but it needs sufficient time for a considerable change (Holechek et al., 1989). A decrease in O.M. with increase of erosion is hypothesized (Khan et al., 2003) and soil and water conservation measures increased the soil O.M. content (Kinati, 2006). Soil loss, nutrient mining and insufficient supply of chemical fertilizers and organic amendments could be the reasons of low O.M. in rainfed sloppy lands (Rashid and Qayyum, 1990) and these lands can be save by appropriate supply of nutrients and suitable soil and water conservation measures (Fatondji, 2002).

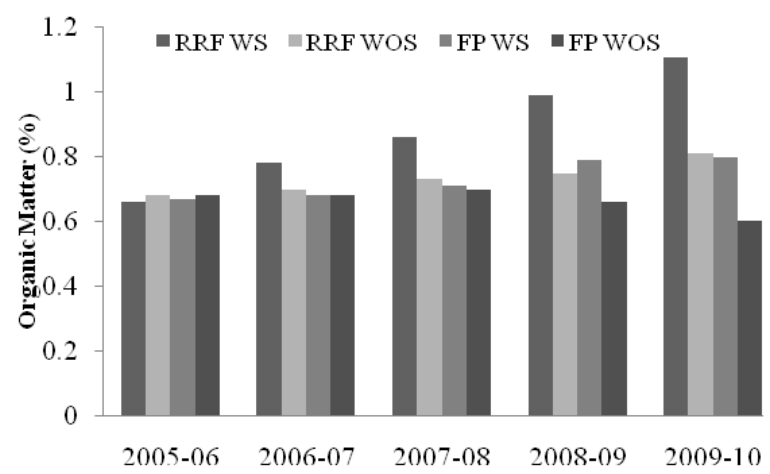

Figure 5. Effect of TS on soil organic matter 
Data showed that soil $\mathrm{P}_{2} \mathrm{O}_{5}$ was increased from 3.90 to 4.96 $\mathrm{mg} \mathrm{kg}^{-1}$, in RRFWS during 2005-2010 while it was decreased from 2.92 to $2.22 \mathrm{mg} \mathrm{kg}^{-1}$ in FPWOS (Fig. 6). It clearly indicated that TS has marked significant impact in determining the soil available P. The rank order of treatments of this study was RRFWS $>$ FPWS $>$ RRWOS $>$ FPWOS. It was also noticed during this study that TS enhance the efficiency of inputs in both cases i.e., RRF and FP. Availability of soil moisture contents through reduction in run off may have enhanced the availability of soil $\mathrm{P}_{2} \mathrm{O}_{5}$ and the stability of organic carbon through maintenance of O.M. could be another reason of availability of soil $\mathrm{P}_{2} \mathrm{O}_{5}$ (Singh et al., 2012). The overall inadequacy of available phosphorus during this experiment could be due to parent material: the low record of available phosphorus content might be because of the erosion. Our results justify the Vancampenhout (2003); noted that available phosphorous increases when soil loss was reduced compared with eroded soils. Gete (2000) also confirmed that erosion depletes the available $\mathrm{P}$ and generally Pakistani soils are deficient in many essential nutrients since they are developed from calcareous alluvium and loess material (Chaudry et al., 2007).

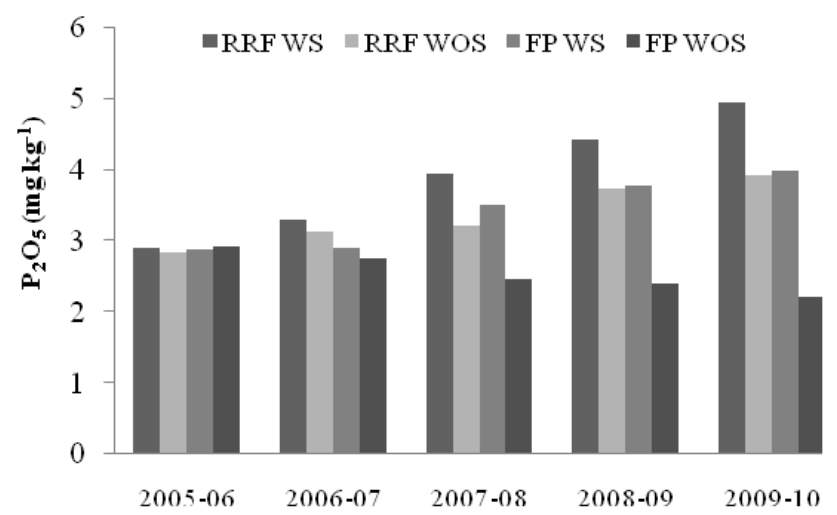

Figure 6. Effect of TS on available $\mathrm{P}_{2} \mathrm{O}_{5}$.

Data regarding extractable potassium (Fig. 7) indicated that extractable potassium also increased significantly in the treatments with TS particularly in RRFWS (64 to $84 \mathrm{mg} \mathrm{kg}^{-1}$ ) and accelerated erosion through run off has diminished extractable potassium level (62 to $46 \mathrm{mg} \mathrm{kg}^{-1}$ ) in treatments WOTS since such measures are adopted to minimize soil erosion and to control soil loss to conserve soil moisture and soil fertility (Xiao-yan et al., 2004). Soil and water conservation practices also diminishes the negative effect of torrential rains and can enhance the amount of soil O.M., $\mathrm{Mg}$, $\mathrm{Ca}$ and K (Abu Hammad et al., 2006). Poor CEC could be another reason for lesser availability of extractable potassium (Elam et al., 1995)

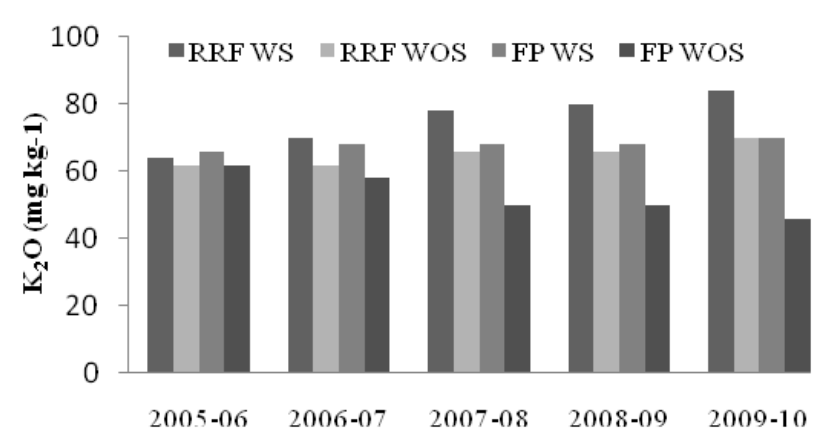

Figure 7. Effect of TS on Extractable $\mathrm{K}_{2} \mathrm{O}$

Change in soil moisture contents: Soil moisture contents (Fig. 8) increased significantly by TS which is the most important concern in rainfed region. Maximum soil moisture contents were recorded (15.10\%) in RRFWS in 2008-09. Five years data of this study revealed that average maximum moisture contents $(12.70 \%)$ were determined in RRFWS followed by $10.78 \%$ in FPWS while the lowest average soil moisture contents $(9.09 \%)$ were determined in FPWOS. The main benefit of TS was the improvement of water holding capacity of soils (Zougmore et al., 2000) by lowering bulk density of TS soils (Yihenew, 2009). The variation in soil moisture may be resulted due to topography, soil type, vegetative cover, land use and management strategies ( $\mathrm{Fu}$ et al., 2003). TS have intercepted the run off by reducing its velocity which consequently enhanced water holding capacity and increased soil moisture contents. Our results are in line with Al-Kharabsheh (2004) Mugabe (2004) also reported a significant increase in soil moisture by in-situ conservation practices. For maximum retention of soil moisture, availability and uptake of soil nutrients; erosion control and soil fertility improvements are needed (Rockstrom and Falkenmark, 2000).

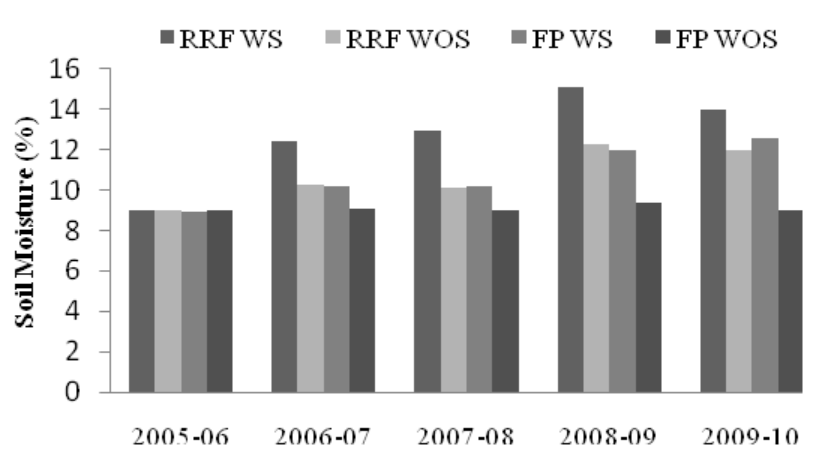

Figure 8. Effect of TS on Soil Moisture Contents

Conclusions: Soil and water conservation practices including TS have ability to intercept rain water and enhance the soil moisture contents for crop use. TS significantly increased the soil moisture (16\%) and minimized the soil sediment loss consequently soil nutrient loss was diminished significantly 
which in response increased the wheat yield $20 \%$ from $2005-$ 10. A substantial decrease in gully development and soil loss was observed by reduction in run off. Farmers are recommended to adopt TS for efficient retention of soil moisture which has ability to minimize the run-off and soil loss. But, they are also advised balanced addition of essential soil nutrients to obtain maximum benefits.

\section{REFERENCES}

Abu Hammad, A., T. Borresen and L.E. Haugen. 2006. Effect of rain characteristics and terracing on runoff and erosion under the Mediterranean. Soil \& Till. Res. 87: 39-47.

Ahmad, N. and M. Rashid. 2003. Fertilizers and their use in Pakistan. Extension Guide, Islamabad, Pakistan.

Akhtar, A., M. Rashid, A. Ali, M. Mushtaq, A. Majid and A.B. Salkini. 2004. Review of agriculture in the dry areas. ICARDA Caravan No. 20/21, June/December 2004.

Ali, I., F. Khan and A.U. Bhatti. 2006. Some physicochemical properties of soil as influenced by surface erosion under different cropping systems on uplandsloping soil. Soil \& Environ. 25: 28-34.

Al-Kharabsheh, A. 2004. Effect of rainfall and soil surface management on soil water budget and erosion in arid areas. M.Sc. Thesis, University of Jordan, Amman. Jordan.

American Society of Agronomy. 1965. Methods of Soil Analysis. Part I. Amer. Soc. of Agron., Inc., Publisher Madison, Wisconsin, USA. pp. 82-93.

Ayalew, A. 2011. Construction of soil conservation structures for improvement of crops and soil productivity in the Southern Ethiopia. J. Environ. and Earth Sci. 1: 22243216.

Bosshart, U. 1997. Catchment discharge and suspended sediment transport as indicators of physical soil and water conservation in the Mayketin Catchment, Afdeyu Research Unit. A Case Study in the Northern Highlands of Eritrea. Bern, SCRP. Research Report 39: 137.

Chaudry, E.H., V. Timmer, A.S. Javed and M.T. Siddique. 2007. Wheat response to micronutrients in rain-fed areas of Punjab. Soil \& Environ. 26: 97-101.

Elam, M., S. Ben-Ari and H. Magen. 1995. The dissolution of different types of potassium fertilizers suitable for fertigation. Proc. Dahlia Greidinger Int. Symp. Fertigation. pp. 165-174.

Eswaran, H.R., R. Lal and P.F. Reich. 2001. Land degradation: an overview, Responses to Land Degradation. In: E.M. Bridges, I.D. Hannam, L.R. Oldeman, F.W.T. Pening de Vries, S.J. Scherr and S. Sompatpanit (eds.), Proc. $2^{\text {nd }}$ Int. Conf. Land Degradation and Desertification, Khon Kaen. Oxford Press, New Delhi, India.
FAO. 1990. Field Manual of Agricultural Engineering. U.S Department of Agriculture, USA.

Fatondji, D., 2002. Organic fertilizer decomposition, nutrient release and nutrient uptake by millet crop in a traditional land rehabilitation techniques (Zai), in the Sahel. ZEF Ecology and Development Series No. 1, Cuvillier Verlag, Bonn.

Fu, B., J. Wang, L .Chen and Y. Qiu. 2003. The effect of land use on soil moisture variation in Danagou catchment of the Loess Plateau, China. Catena 54:197-213.

Fu, B.J., L.D. Chen, K.M. Ma., H.F. Zhou and J. Wang. 2000. The relationship between land use and soil conditions in the hilly areas of the Loess Plateau in northern Shaanxi, China. Catena 36: 69-78.

Garcia, D.M.L.F., Y. Rharrabti, D. Villegas and C. Royo. 2003. Evaluation of grain yield and its components in durum wheat under Mediterranean conditions: An ontogenic approach. Agron. J. 95: 266-274.

Gardner, R.A.M. and A.J. Gerrard. 2003. Runoff and soil erosion on cultivated rainfed terraces in the Middle Hills of Nepal. Appl. Geograph. 23: 23-45.

Gee, G. and W. Bauder. 1986. Particle size analysis. In: A. Klute (ed.), Methods of Soil Analysis, Part I, $2^{\text {nd }}$ Ed. Aron. Monogr. 9. ISSSA, Madison, WI. pp.383-409.

Gete, Z. 2000. Landscape dynamics and soil erosion process modeling in the north-western Ethiopian highlands. African Studies Series A16. Berne: Geographica Bernensia.

Holechek, J., R. pieper and C. Herbel. 1989. Range Management Principles and Practices, $2^{\text {nd }}$ Ed. Prentice Hall, Englweood Cliffs, New Jersey.

Izaurralde, R.C., S.S. Malhi, M. Nyborg, E.D. Solberg and M.C.Q. Jakas. 2006. Crop performance and soil properties in two artificially eroded soils in north-central Alberta. Agron. J. 98: 1298-1311.

Kaihura, B.S., I.K. Kullaya, M. Kilasara, J.B. Aune, B.R. Singh and R. Lal. 1999. Soil quality effects of accelerated erosion and management system in three eco-regions of Tanzania. Soil and Till. Res. 53: 59-70.

Khan, F., W. Ahmad, A.U. Bhatti and R.A. Khattak. 2003. Effect of soil erosion on physical properties of some soil series in NWFP, Pakistan. Pak. J. Soil Sci. 22: 36-42.

Kinati, C., 2006. The effect of integrated soil and water conservation measures on soil physical and chemical properties: A case for Enebsie Sar Midir Wereda, Ethiopia. A Thesis Paper, Mekelle University, Mekelle.

Lal, R., 2001. Soil degradation by erosion. Land Degrad. \& Develop. 12:519-539.

Mando, A. 1998. Soil dwelling termites and mulch improve nutrient release and crops performance on crusted Sahelian soils. Arid Soil Res. Rehabil. 12:153-164.

Mando, A., A.R. Zougmore, N.P. Zombrea and V. Hien. 2000. Rehabilitation des sols deẦradeÂs dans les zones semi-arides de l'Afrique sub-saharienne. In: C. Floret and 
R. Pontanier (eds.), La JacheÁre en Afrique Tropicale; de la JacheÁre Naturelle aÁ la JacheÁre AmeÂlioreÂe: le Point des Connaissances. John Libbey Eurotext, Paris, in Press.

McLean, E.O. 1982. Soil pH and lime requirement. In: A.L. Page (ed.), Methods of Soil Analysis, part 2: Chemical and microbiological properties. Am. Soc. Agron. Madison, WI, USA. pp.199-224.

Mugabe, F.T. 2004. Evaluation of the benefits of infiltration pits on soil moisture in semi-arid Zimbabwe. J. Agron. 3: 188-190.

Nasri, S., J. Albergel and C. Cudennec. 2004. Hydrological processes in macrocatchment water harvesting in the arid region of Tunisia: the traditional system of tabias. Hydrol. Sci. J. 49: 261-272.

Nyssen, J., J. Poesen, M. Haile, J. Moeyersons and J. Deckers. 2000. Tillage erosion on slopes with soil conservation structures in the Ethiopian highlands. Soil Till. Res. 57: 115-127.

Prinz, D., L. Pereria, R.A. Feddes, J.R. Gilleym and B. Lessaffre. 1996. Water harvesting past and future. University of Karlsruhe, Institute of Hydraulic Structures and Rural Engineering, D-76128 Karlsruhe, Germany. Proc. NATO Advanced Research Workshop, Vimeiro, Portugal. pp 137-168.

Prinz, D. and A. Malik. 2005. Runoff farming. WCA infoNET, p.39.

Qiu, Y., B. Fu., J. Wang and L. Chen. 2003. Spatio-temporal prediction of soil water content using multiple linear regressions in a small catchment of the Loess Plateau, China. Catena 54: 173-195.

Rashid, A. and F. Qayyum. 1990. Cooperative research program on micronutrient status of Pakistan soils and their role in crop production. Final Report 1983-90. National Agricultural Research Center Islamabad, Pakistan.

Reconnaissance Soil Survey Campbellpur. 1970. Soil Survey of Pakistan.

Rhoades, J.D. 1982. Cation exchange capacity. 149-158 In: A.L. Page (ed.), Methods of Soil Analysis, Part 2. Chemical and Microbiological Properties. Am. Soc. Agron., Madison, Wisconsin, USA.

Richards, L.A. 1954. Diagnosis and improvement of saline and alkali soils. USDA Handbook 60.

Rockstrom, J. and M. Falkenmark. 2000. Semiarid crop production from a hydrological perspective: gap between potential and actual yields. Critic. Rev. Plant Sci. 19: 319-346.

Safene, C., A. Ayalew, W. Mazengia and T. Amede. 2006. Integrating various biological measures of erosion control and soil fertility management: The case of Gununo, Ethiopia. In: T. Amede, L. German, S. Ra, C. Opondo and A. Stroud (eds.), Integrated Natural Resources Management in practice: Enabling communities to improve mountain livelihoods and landscapes. Proceedings of conference held on October 12-15.

Saleh, H. Al-Seekh and A.G. Mohammad. 2009. The effect of water harvesting techniques on runoff, sedimentation, and soil properties. Environ. Manag. 44:37-45.

Schiettecatte, W., M. Ouessar, D. Gabriels, S. Tanghe, S. Heirman and F. Abdelli .2005. Impact of water harvesting techniques on soil and water conservation: a case study on a micro catchment in southeastern Tunisia. J. Arid Environ. 61:267-313.

Shemdoe, R.S., I.S. Kikula, P.V. Damme and W.M. Cornelis. 2009. Tillage practices and their impacts on soil fertility in farmers' fields in semi-arid central Tanzania. Arid Land Res. and Manag. 23: 168-181.

Singh, G., A.U. Khan, A. Kumar, N. Bala and U.K. Tomar. 2012. Effects of rainwater harvesting and afforestation on soil properties and growth of Emblica officinalis while restoring degraded hills in Western India. African J. Environ. Sci. Tech. 6: 300-311.

Steel, R.G.D., J.H. Torrie and M.A. Boston. 1997. Principles and Procedures of Statistics: A biometrical approach. McGraw Hill Book company Inc. New York. p.633.

Tesfaye, E. 2008. Continued use of soil and water conservation practices: A case study in Tulla district, Ethiopia. M.Sc. Thesis, Wageningen University, The Netherlands.

Vancampenhout, K. 2003. Consequence of stone bund implementation in the Highlands of Northern Ethiopia. M.Sc. Thesis, Katholieke University Leuven, Belgium. p.86.

Waga, M., D. Gamiyo, T. Amede, M. Daka and J. Mowo. 2007. Challenges of collective action in soil and water conservation: The case of Gununo Watershed, Southern Ethiopia. African Crop Science Conference Proceedings El-Minia, Egypt . pp.1541-1545.

Walkley, A. and C.A. Black. 1947. An examination of Degtjareff methods for determining soil organic matter and proposed modifications of the chromic acid titration method. Soil Sci. 37: 29-38.

Watanabe, F.S. and S.O. Olsen. 1965. Method for determination of phosphorus in water and $\mathrm{NaHCO}_{3}$ extracts from soil. Soil Sci. Soc. Am. Proc. 29:677-678.

Xiang, X., Z. Hong-Wu and Z. Ouyang. 2004. Development of check-dam systems in gullies on the Loess Plateau, China. Environ. Sci. Policy 7: 79-86.

Xiao-Yan, L., Z. Xie and X. Yan. 2004. Runoff characteristics of artificial materials for rainwater harvesting in the semiarid regions of China. Agri. Water Manag. 65:211224.

Youasf, M. 2007. Crop management in rainfed areas. The Daily DAWN, October 17, 2007.

Zougmore, R., S. Guillobezb, N.F. Kamboua and G. Sonc. 2000. Runoff and sorghum performance as affected by 
the spacing of stone lines in the semiarid Sahelian zone. Soil \& Till. Res. 56: 75-183.

Zougmore, R., Z. Gnankambary, S. Guillobez and L. Stroosnijder. 2002. Effects of stone lines on soil chemical characteristics under continuous sorghum cropping in semiarid Burkina Faso. Soil \& Till. Res. 66: 47-53. 